\title{
PERCEIVED EFFECTS OF MICROFINANCE ON WOMEN EMPOWERMENT IN LA- NKWANTANANG-MADINA MUNICIPALITY
}

\author{
*Ayam, J., Abangbase, F., Doku, C. \& Dadzie, E. N. \\ University of Professional Studies, Accra Ghana \\ Corresponding Author's Email: ayamjoseph@gmail.com
}

\begin{abstract}
This paper examines the impact of microfinance on women empowerment through a cross-sectional survey with a total of 189 respondents in La-Nkwantanang municipality. Paired sample t-test was performed to analyse the situation before and after joining Microfinance Institutions (MFIs) to access credit facilities. Women empowerment is measured using three indicators namely: standard of living; generation of income from business operation; and participation in decision making at the family level. The main effects of microfinance services computed using the summated scale were found to suggest an improved standard of living with an average mean score of 1.5234 and standard deviation of 0.84099, improvement in business operations with a score of 1.4769 and standard deviation of 0.98718 and enhanced participation of women in decision making with a mean of 1.38378 and standard deviation of 0.98287. The paired sample test results indicated a p-value of 0.000 which is less than 5\% ( $p<0.05)$. This study confirms the view that access to micro credit after joining MFIs, increased participants' incomes and savings, improved their standard of living and increased their participation in decision making within the family. Based on the findings, it is recommended that MFIs should expand their financial advisory services to ensure the prudent utilisation of micro credit. Government must design appropriate micro credit policies that support this expansion.
\end{abstract}

\section{Keywords: Microfinance, Women Empowerment, Survey, Ghana}

\section{Introduction}

Women empowerment since its conceptualization within the gender and development literature over the last few decades has remained an important policy initiative attractive to many developing economies across the sub-Saharan region towards addressing gender segregation and poverty. Thus, women empowerment has become an essential policy tool in Ghana over the last few years given the fact that women have been discriminated against in every sphere of life. Prior literature provides evidence to suggest that about $70 \%$ of poverty among women is attributed to geographical, economic, social, cultural and political factors in Africa (Pokhriyal et al., 2014). Women in both rural and urban areas across the sub-Saharan region face a higher risk of poverty and more limited economic opportunities compared to their male counterparts (Pokhriyal et al., 2014). Historically, women have been marginalised and subjected to the control of men through cultural and institutional exclusion (Kato \& Kratzer, 2013). Thus, empowering women in Ghana has become a necessary tool for promoting inclusive development through poverty reduction. It is important to argue that women's empowerment is much more than the ability to make choices but includes the capacity to bring to reality one's personal goals and desires. This means that the availability of resources to women and their control 
over these resources is very key to empowering them to generate income, participate in family decision making and improve their living standards with spill-over effects on the family. There is a wellestablished strand of literature on the impact of microfinance and development across the world. However, this paper examines the impact of women access to micro credit on empowerment through the lens of three indicators - (i) standard of living, (ii) generation of income from business operation and (iii) participation in decision making at the family level. The study contributes towards an understanding of a new dimension to women empowerment in Africa.

Women empowerment, thus, is a process to enhance women's capacity for self-determination or agency to meet their practical and strategic needs, through which they can have equal rights, power and resources with men in society (Drolet, 2010). Given that women constitute over 50 percent of the global population, their role in the development of Ghana's growing economy cannot be over emphasized. As a result, there is the need for women to have equal access to resources to increase their level of participation in today's competitive global economy (Pokhriyal et al., 2014). Prior literature supports the argument that micro financing models remains the most appropriate and feasible strategy to empower women (Kato \& Kratzer, 2013). The concept of micro financing involves providing services such as savings, loans, remittances and insurance to poor and low-income households which do not have access to financing from commercial banking services. According to Gundappa (2014) and Addae (2015), microfinance is regarded as an effective financing model to help low-income households take advantage of economic opportunities and improve their standard of living. Wrigley-Asante (2012) contend that majority of micro finance programmes have over the years targeted women as an avenue to empowering them. Lyngdoh and Pati (2013) argued that the rationale for providing micro credit or loans to women is based on prior findings that women are discriminated against in the formal labour market disproportionately which has led to vulnerability. Though the concept of micro financing was to promote the financial inclusion of women, yet, access to micro credit has been a major problem for women in Ghana and other developing countries (Ahiawodzi \& Adade, 2012). This is because, women are regarded as the poorest or most vulnerable in the society and as such do not have collateral to secure credit from financial institutions (Gundappa, 2014). Drawing from the case of Ghana, there have been many interventions by various governments and non-governmental organisations such as the establishment of Microfinance and Small Loans Centre (MASLOC) by the government of Ghana, and Small Business Loan Portfolio Guarantee (USAID) and Micro Start Ghana Programme established by NGOs and international development agencies to empower women and eradicate poverty through access to micro credit. Despite the various policy interventions from governments and international development agencies, research on women empowerment is still limited within the lens of Ghana in the literature. This study, thus, contributes to addressing the limited literature by examining how access to micro credit among women can impact on their empowerment. This study, therefore, attempts to find out the effect of micro credit access on women empowerment in Ghana in the La-NkwantanangMadina Municipal which is characterised by micro businesses engaged by mostly women in the area. The study addresses the research question: How does access to microfinance empower women in the La-Nkwantanang-Madina Municipality?

\section{The Theoretical Framework \\ Microfinance and Women Empowerment Paradigms}

Within the evolving literature, several theories have been developed to examine the empowerment of women through microfinance. Mayoux (2000; 2006), identified three contrasting paradigms with different underlying aims and understandings, different policy perceptions and priorities in relation to both microfinance and gender policy mix. First, Mayoux (2000) advanced the poverty alleviation 
paradigm: the model assumes that increasing women's access to microfinance will enable women to make a greater contribution to household income and this, together with other interventions help to increase household well-being, or translate into improved well-being for women and enable them to bring about wider changes in gender inequality. The main considerations of the poverty alleviation paradigm of microfinance are: poverty reduction among the poorest, increased well-being and increase community development. Thus, the focus of the poverty alleviation paradigm is on small savings and loans provision for consumption and production (Mayoux, 2006). The second is the Feminist empowerment paradigm. This model assumes that women's empowerment requires fundamental change in the macro level development agenda as well as explicit support for women to challenge gender subordination at the micro-level. Within the feminist empowerment paradigm, microfinance is promoted as an entry point in the context of a wider strategy for women's economic, social and political empowerment which focuses on gender awareness and feminist organization (Mayoux, 2006). The third is the financial selfsustainability paradigm. This model assumes that increasing women's access to microfinance services will automatically lead to poverty reduction and women economic empowerment. The financial selfsustainability theory is adopted for this study due to its emphasis on financially sustainable microfinance programmes, which promote increasing access to microfinance services for large women and vulnerable groups in society. The financial selfsustainability theory is in tangent with the main objective of the study which seeks to assess the effect of microfinance on the empowerment of women.

According to Mayoux (2006), gender lobbyists and policy commentators have advocated for targeting women on the basis of high female repayment rates and contribution of women economic activities to economic growth and inclusive development. The financial self-sustainability theory postulates that empowerment is the expansion of individual choices and capacities for self-reliance. It assumed that increasing the number of women beneficiaries will in itself lead to increased individual economic empowerment. It is then concluded that increased economic empowerment will lead to increased wellbeing of women's social and political empowerment. However, this theory is criticized on the basis that the poorest of the poor are left out of microfinance programmes as they target clients who are more accessible and can repay (Edward \& Olsen, 2006).

\section{Impact of Microfinance on Women Empowerment} There is consistent evidence within the literature to argue that women empowerment through microfinance can positively transform women in two ways. Firstly, Li et al. (2011) found that microfinance supports poor women to earn income independent of their spouses to financially support their families, which immediately boosts their selfesteem. Secondly, microfinance emancipates women from household limitations and more into a wider community as they access credit and use the credit facility to generate income (Addae, 2015; Li et al., 2011). Indeed, by being exposed to the wider community coupled with the interaction with other women within the community, their self confidence is significantly enhanced ( $\mathrm{Li}$ et al., 2011). In a study by Swain (2006), the author reported that microfinance has a definite economic impact on households, with increases in income and declining vulnerability. The study further revealed a significant impact on Self Help Group (SHG) households in terms of control, management ability, self-confidence, change in behaviour and decision making. The study thus concluded that apart from social empowerment, the SHG household also demonstrates greater awareness and participation in local politics and governance.

In a similar vein, Addae (2015) also affirms the fact that microfinance through microcredit has positively improved the wellbeing of women. However, most of these studies have considered only an aspect of women's empowerment and largely at household level. For example, Gangadhar and Malyadri's 
(2015) study revealed that microfinance is an effective tool in improving women's empowerment in areas of household economic decision making, legal awareness, mobility, economic security and family decision making. On one hand, several critics of micro credit programmes argue that micro credit alone is not a solution for women empowerment (Wrigley-Asante, 2012). There is, therefore, the need for greater understanding of the ways in which different types of micro credit products and services of MFIs affect women and support their empowerment. This kind of information will potentially help in informing policy makers on avenues to empower women in developing economies including Ghana.

\section{Methods and Materials Research Design}

This study is grounded on a quantitative study design. Quantitative study design remains an important research paradigm in social science research owing to its trustworthiness, objectivity and the ability to generalise the study findings. A descriptive survey was used in conducting this study because it dealt with questions and opinions of existing issues. Quantitative study design supports investigations that seek to influence policy as objectivity and a capability to generalise the research findings is premium. According to Quartey and Awoyemi (2002), the descriptive survey design does not only uncover data for its synthesis but integrates data and points to implication and interrelationships.

\section{Population and sample}

As far as the subject matter is concerned, the target population of the study comprises all micro or medium women entrepreneurs operating small and micro businesses who have accessed microfinance products and services within the La- NkwantanangMadina Municipality. The list of all registered micro finance institutions was sourced from the Bank of Ghana website based on which the list of all MFIs operating in the La- Nkwantanang-Madina Municipality were identified. Based on this approach we settled on six microfinance institutions out of a total of fifteen registered and recognized
MFIs operating within La-Nkwantanang Madina Municipality. The sampled MFIs in this study represent over $60 \%$ of the total population of MFIs. We then applied simple random sampling technique to determine the sample size of six. In quantitative study design, simple random sampling gives equal opportunity for each sample to be chosen entirely by chance and each member of the population has an equal chance of being included in the sample. The computed sample size based on a population of 921 and $95 \%$ confidence level was derived to be 200 for all six microfinance institutions.

\section{Data Collection procedure}

A questionnaire was the main instrument used to obtain primary data in order to get an in-depth understanding from women clients of microfinance institutions. In administering the questionnaire, the researchers conducted personal interviews with the women because most of them are illiterates. Thus, it was very key for the researchers to explain the content of the questionnaire to them and to help them in completing the said questions. The convenience sampling approach was used in collecting data from women clients from the six MFIs in the study sample. A structured questionnaire with "Likert five-point scale" was used as the measurement instrument. A Likert scale is a type of rating scale used to measure attitudes or opinions. With this scale, respondents were asked to rate items on a level of agreement. For example, prior research suggests that "Likert five-point scale is more appropriate for this kind of study (Khan \& Rahaman, 2007). Questions were very specific with the "Likert fivepoint scale" which were based on the satisfaction level of the different variables related to living standard of women, enterprises operated by women clients and household decision making. Existing literature argued that these three key variables are important determinants of women empowerment in developing societies (Khan \& Rahaman, 2007).

\section{Validity and Reliability}

The researchers used a pre-testing survey or pilot study to test the validity of the questionnaire. The 
pre-testing of the questionnaire was done with a sample of 15 potential respondents and their responses were evaluated for potential problems. The questionnaire was then modified and used for the data collection. The researchers used the Cronbach Alpha Coefficient in determining whether the study instrument was reliable enough to collect the data towards achieving the objectives for the study. The researchers obtained a Cronbach alpha coefficient greater than 0.7 which indicated that the study instrument was reliable enough (Taber, 2018).

\section{Data analysis}

The data was analysed in line with the objectives of the study. Descriptive statistics such as tables, bar charts, histogram and pie chart were used. The statistical package for social science (SPSS v16) was used to run the data analysis. To find out the impact of microfinance on the respondents before and after joining MFIs, the paired sample t-test was employed. The researchers used the descriptive statistical tool in computing the variables of each construct into one aggregated variable score. As a result, the researchers were able to come up with three major aggregated variables namely: Respondents' Standard of Living Before and After
Joining MFIs; Respondents' Business Operation Before and After MFIs and Respondents' Decision Making Before and after joining MFIs.

\section{Results}

\section{Demographic characteristics of respondents}

The total number of respondents was 189 of which $1.6 \%$ were 20 years and below, whilst $4 \%$ of the respondents were over 50 years old. The majority of the beneficiaries of micro finance services were within the 21-30-year-old bracket which represented a total of $37 \%$. This was followed closely by the $31-$ 40-year-old group as well as 41-50-year bracket with $32.3 \%$ and $27 \%$ respectively. This indicates that the age cohort structure of micro-finance clients in La-Nkwantanag-Madina Municipal is predominantly middle-aged women. This finding corroborates with prior literature that middle aged women in the Ghanaian society are the most economically active section of the population who have the potential to engage in micro businesses such as petty-trading. The results show that majority of the women are those in the economically active bracket who are poised to engage with MFIs to their own advantage and that of their individual family.

\section{Figure 1: Age Distribution of Respondents}

\section{Age of Respondents}

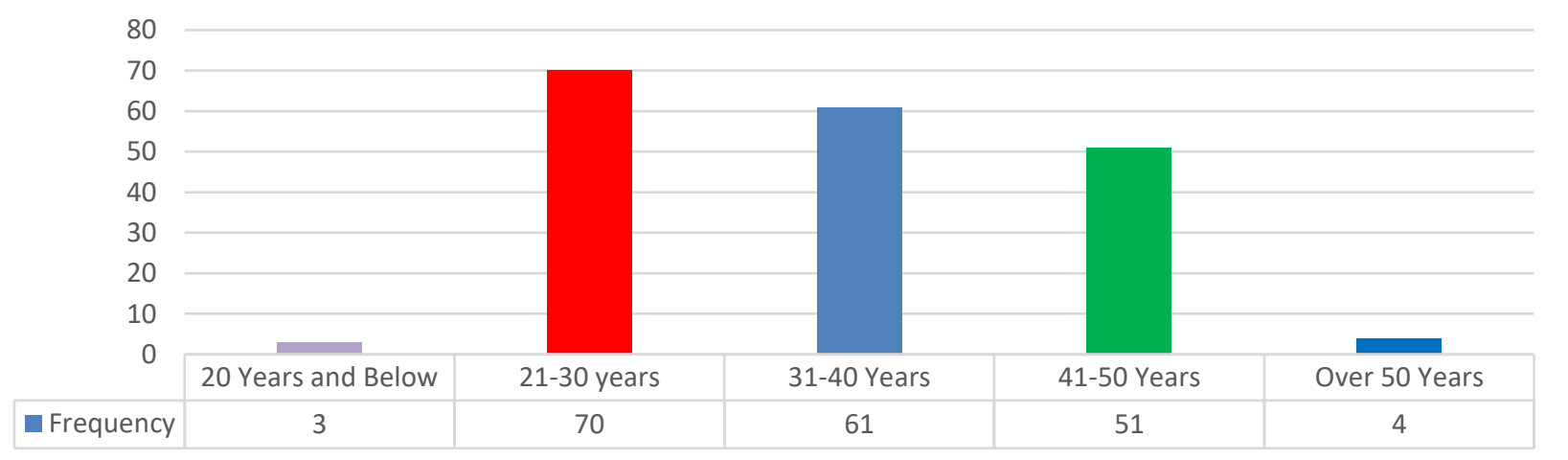

Source: Field survey (2016)

The respondents were asked to state their marital status and the findings are as shown in figure 2 below. Based on the results, most of the respondents (54\%) were married, only $20 \%$ of the total respondents were single and $11 \%$ were divorced while $9 \%$ were widowed. 
Figure 2: Marital Status of Respondents

\section{Marital status}

\section{- Single Married Divorced \\ Widow Separated}

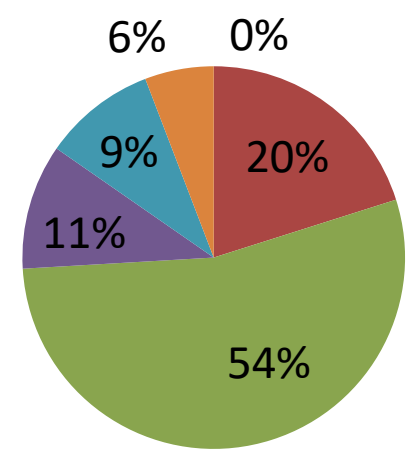

Source: Field survey (2016)

From figure 3, six respondents were associated with microfinance institutions since 1996 and 2000.
About 17 respondents identified themselves to have joined microfinance institutions between 2001 and 2005 while 63 respondents joined between 2006 and 2010. However, it was observed that, majority of the respondents (102) started to benefit from microfinance institutions in 2011/2015 thereabout. Only one respondent identified herself to have joined a microfinance institution within the boundary period of 2016/2020. This can be attributed to the recent microfinance scandal involving some major microfinance institutions across the country, creating fear and panic among clients. This shows that, most of the respondents have associated themselves with the financial institutions for more than 10 years. The implication of this number of years' affiliation with MFIs is that most of the respondents have been with the MFIs long enough for them to know the improvement that MFIs have had on their lives and business operations over a reasonable period of time.

\section{Figure 3: Year of Joining MFIs}

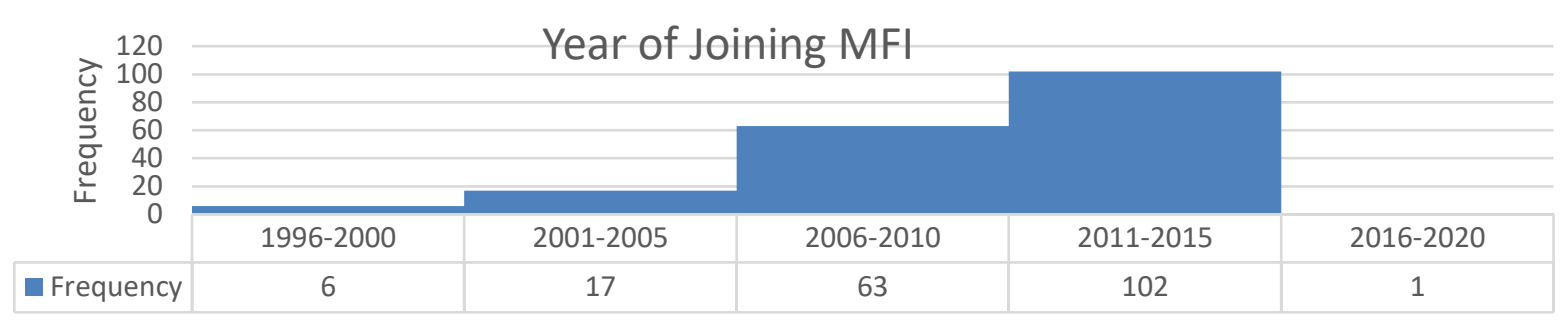

Class Boundaries

Source: Field survey (2016)

\section{MFIs Products/Services offered to clients}

Figure 4 below shows the kind of products and services the respondents have received from their respective microfinance institutions. Since each respondent could use any of the various products and services identified by the researchers, their responses were analysed using the multiple response analytical statistical technique. The results indicated that, out of the three products/services provided, 139 (73.5\%) representing majority of the respondents received credit or loans from the MFIs. Also, 78 $(41.30 \%)$ of the respondents patronize the various savings products from the MFIs with the least 
patronized service is financial advisory, which had $39(20.60 \%)$ respondents patronizing it.

Figure 4: Products/Services offered to clients

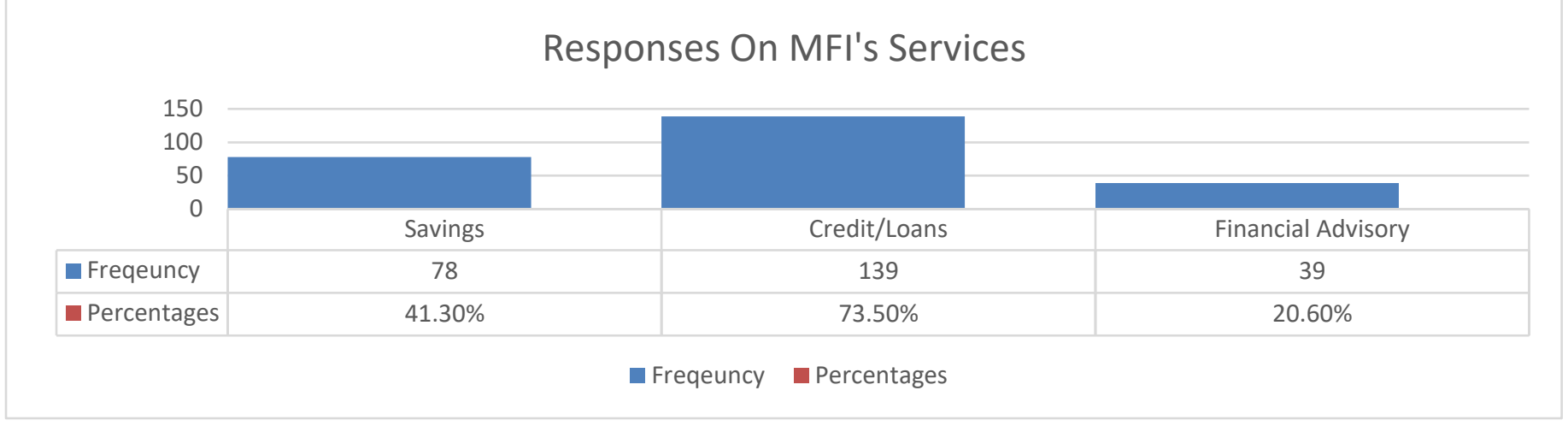

Source: Field survey (2016)

\section{Impact of MFI on Standard of Living}

From Table1, the respondents' ability to buy clothing before joining MFIs had a mean of 2.53 which signifies that the respondents were uncertain whether they had an improved ability to buy clothing before joining MFIs. On the other hand, the respondents agreed that they had improved ability to buy clothing after joining MFIs with a mean of 4.17. Moreover, the respondents were uncertain (mean: 2.55) as to whether they were able to provide nutritious food prior to joining MFIs but however agreed (mean: 4.12) that they were able to provide nutritious food afterwards. In addition, the respondents were uncertain (2.65) as to whether they were able to provide three square meals daily before MFIs but agreed (mean: 4.20) that they were able to provide three square meals daily after MFIs. The respondents were also uncertain (mean: 2.65) as to whether their children's education had improved before joining MFIs but agreed that it has improved significantly after MFIs. The respondents also indicted that they now have better access to health care after joining MFIs with a mean of 4.29 as against a mean of 2.76 before joining MFIs.

Table 1: Respondents Descriptive Statistics on Standard of living Before and After Joining MFI

\begin{tabular}{lllll}
\hline Variables & Before & After & \\
Mean & Std. Deviation & Mean & Std. Deviation \\
\hline Better clothing & 2.53 & 1.01 & 4.17 & 0.95 \\
Nutritious food & 2.55 & 1.02 & 4.12 & 0.82 \\
Three square meals daily & 2.76 & 1.07 & 4.20 & 0.90 \\
Children's education & 2.65 & 0.94 & 4.14 & 0.73 \\
Health Care & 2.76 & 1.02 & 4.29 & 0.83 \\
\hline
\end{tabular}

Source: Field survey (2016)

The mean differences of standard of living indicated that there had been an improvement in the standard of living of the respondents after they started receiving services from micro finance institutions. The paired test all obtained a p-value of 0.00 which is less than $5 \%$. As a result, the researchers concluded that there had been a significant improvement of the standard of living of the respondents. 
Table 2: Paired Sample Results for Standard of Living

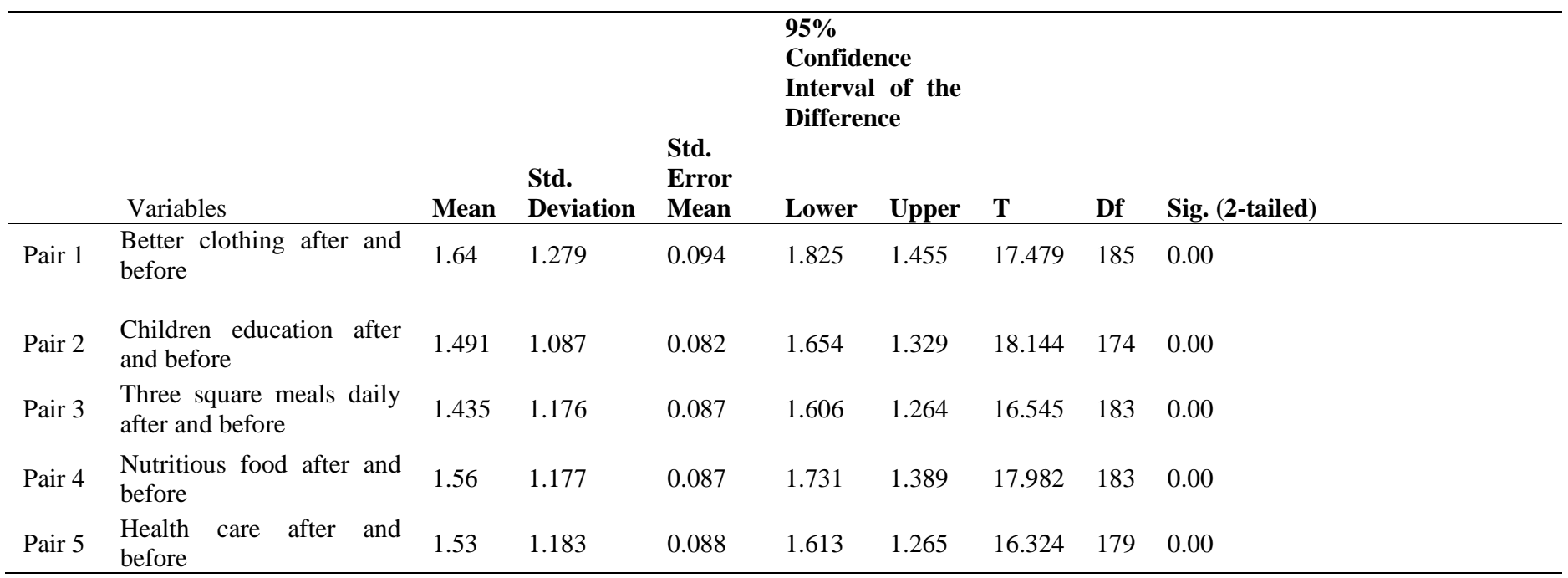

Source: Field survey (2016)

\section{Impact of MFI on Business Operations}

From Table 3, respondents have agreed to an improvement in income after joining micro finance institutions, with a mean of 2.39 and 3.95 before and after respectively. In terms of the ability for additional savings, the respondents agreed that after joining MFIs it has offered them the opportunity to save more with a mean of 4.09 as against a mean of 2.63 before joining micro finance institutions. The respondents also agreed that they are now able to employ more hands to assist with their business operations post microfinance intervention. This is symbolized with means of 2.41 and 3.81 before and after MFIs respectively. Respondents also testified that there had been an improvement in their entrepreneurial skills including financial advisory services and book keeping after joining MFIs with a mean of 4.07 against a mean of 2.43 before MFIs.

Table 3: Respondents Descriptive Statistics on Business Operation Before and After Joining MFI

\begin{tabular}{lllll} 
Variables & $\begin{array}{l}\text { Before } \\
\text { Mean }\end{array}$ & Std. Deviation & $\begin{array}{l}\text { After } \\
\text { Mean }\end{array}$ & Std. Deviation \\
Income & 2.39 & 1.05 & 3.95 & 0.89 \\
Savings & 2.63 & 1.02 & 4.09 & 0.86 \\
Employment & 2.41 & 0.99 & 3.81 & 1.09 \\
Entrepreneurial skills & 2.43 & 1.01 & 4.07 & 0.81 \\
\hline
\end{tabular}

Source: Field survey (2016)

The difference of the sampled test for business operation is indicative of the fact that there has been an improvement in the business operations of the market women. The paired test all obtained a significant p-value less than 0.05 . Hence, the researchers posit that ever since the business women

got affiliated to micro finance institutions for services such as savings, credit or loans and financial advice there has been a significant improvement in the business operation activities of the market women in Madina Municipality. 
95\%

Confidence

Interval of the

Difference

\begin{tabular}{|c|c|c|c|c|c|c|c|c|}
\hline & Mean & $\begin{array}{l}\text { Std. } \\
\text { Deviation }\end{array}$ & $\begin{array}{l}\text { Std. } \\
\text { Error } \\
\text { Mean }\end{array}$ & Lower & Upper & $\mathbf{T}$ & Df & Sig. (2-tailed) \\
\hline Income after and before & 1.557 & 1.207 & 0.089 & 1.733 & 1.381 & 17.455 & 182 & 0.00 \\
\hline $\begin{array}{l}\text { Savings after and } \\
\text { before }\end{array}$ & 1.486 & 1.153 & 0.086 & 1.656 & 1.316 & 17.241 & 178 & 0.00 \\
\hline $\begin{array}{l}\text { Employment after and } \\
\text { before }\end{array}$ & 1.427 & 1.252 & 0.094 & 1.612 & 1.242 & 15.203 & 177 & 0.00 \\
\hline $\begin{array}{l}\text { Entrepreneurial skill } \\
\text { after and before }\end{array}$ & 1.674 & 1.223 & 0.092 & 1.857 & 1.492 & 18.104 & 174 & 0.00 \\
\hline
\end{tabular}

Source: Field survey (2016)

\section{Impact of MFI on Decision Making}

Table 5 depicts the impact of women access to micro finance on decision making prowess at the family level of the respondents. The respondents indicated that they are experiencing an improvement in the participation of household decision making with a mean of 4.21 representing an improvement from 2.88 mean before joining MFIs. The respondents also agreed that their views and opinions are now respected in the family and community level with a supporting mean of 4.19 but the respondents indicated that they are quite uncertain about the level of respect given to their opinions at the community level before joining MFIs.

Table 5: Respondents Descriptive Statistics on Decision Making Before and After Joining MFI

\begin{tabular}{lllll} 
& \multicolumn{2}{c}{ Before } & \multicolumn{3}{c}{ After } \\
Variables & Mean & $\begin{array}{l}\text { Std. } \\
\text { Deviation }\end{array}$ & Mean & Std. Deviation \\
\hline Household level decision making & 2.88 & 1.09 & 4.21 & 0.85 \\
Community level decision making & 2.78 & 1.06 & 4.19 & 0.91 \\
\hline
\end{tabular}

Source: Field survey (2016)

The results from the paired sample indicate that there has been an improvement in participation of market women in decision making within the household much more than they had experienced previously. The differences from the paired sample tests are indicative of the fact that the market women's participation in household decision making has increased. The $\mathrm{P}$ value 0.00 is less than 0.05 . Based on these results, it can be asserted that there has been a significant improvement in the participation of women in household decision making after joining MFIs and gaining micro credit. 


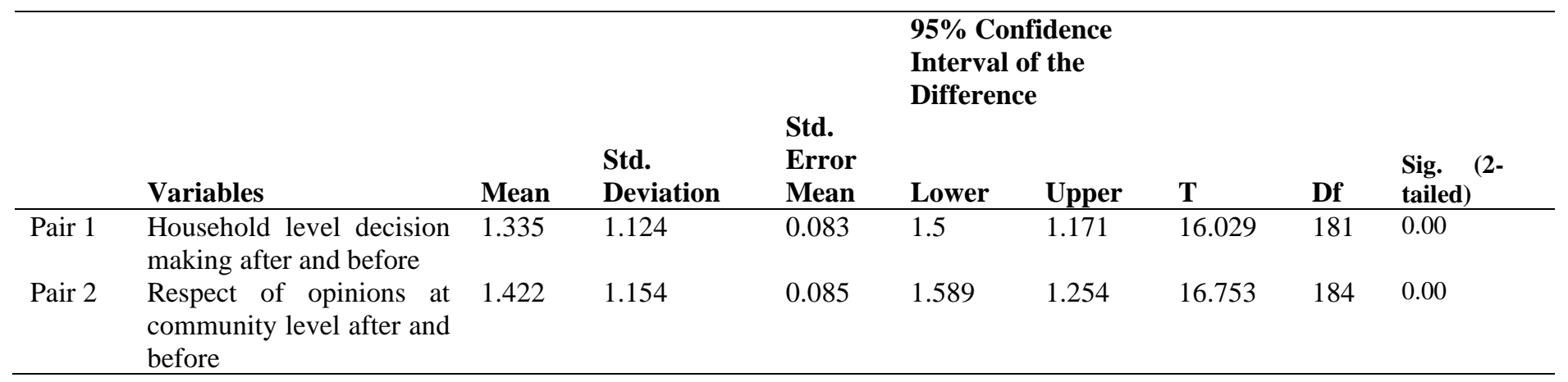

Source: Field survey (2016)

The researchers used a summated scale to compute all the variables of empowerment pre-and post-microfinance intervention. From the results shown in Table 6, it can be seen that the average score of the difference between standard of living of the two periods, that is, before and after is 1.5234 with degrees of freedom of 187 . The tvalue was found to be 24.837 and is significant as the p-value $=0.000(\mathrm{P}<0.05)$. It can, therefore, be argued that the standard of living of women after microfinance intervention is significantly more than prior to microfinance intervention. The average mean score of the differences between business operation before and after microfinance is 1.4769 and the degree of freedom is 183 . The $t$-value was found to be 20.294 which is significant with $\mathrm{p}$-value $=0.000(\mathrm{P}<0.05)$. In addition, this shows that there has been a significant improvement in business operations of women in post microfinance intervention. Women association with MFIs have affected their business activities. Finally, the average mean score of the differences in women participation in decision making pre and post microfinance intervention was found to be 1.38378. The degrees of freedom is 184 with the $t$-value being 19.149. This is significant as the p-value $=0.000(\mathrm{p}<0.05)$. It can be concluded that women participation in household decision making after microfinance intervention improved significantly more than premicrofinance intervention.

Table 7: Paired Sample test differences

95\% Confidence

Interval of the

Difference

\begin{tabular}{|c|c|c|c|c|c|c|c|c|c|}
\hline & & Mean & $\begin{array}{l}\text { Std. } \\
\text { Deviation }\end{array}$ & $\begin{array}{l}\text { Std. Error } \\
\text { Mean }\end{array}$ & Lower & Upper & $\mathbf{t}$ & df & Sig. (2-tailed) \\
\hline Pair 1 & Standard of Living & 1.5234 & 0.84099 & 0.06134 & 1.40241 & 1.6444 & 24.837 & 187 & 0.000 \\
\hline Pair 2 & Business Operation & 1.4769 & 0.98718 & 0.07278 & 1.33331 & 1.62049 & 20.294 & 183 & 0.000 \\
\hline Pair 3 & Decision Making & 1.38378 & 0.98287 & 0.07226 & 1.24121 & 1.52635 & 19.149 & 184 & 0.000 \\
\hline
\end{tabular}

Source: Field survey (2016)

\section{Discussion}

The improvement in the living standards of women can be attributed to the fact that women have direct access to loans and are able to decide what the loans should be used for. The access to these loans has a multiple effect which enables them to expand their business and generate enough income to enhance 
their standard of living. As a result of profits accruing to them, they are able to meet their basic and family needs such as; their ability to provide nutritious food for the family and other important family responsibilities such as the payment of children's school fees, uniforms, books and clothing. Majority of women are also able to buy better clothing as well as the ability to have access to healthcare facilities (ability to pay for the National Health Insurance Scheme). This is supported by a study conducted by Khan and Rahaman (2007), which found out that microfinance has a positive impact on the living standards of the poor people and their lifestyle as well as empowering them

The improvement of business operations stems from the fact that; women are now able to save more because MFIs offered them the platform to make regular savings towards increasing their credit worthiness. Women's demand for credit facilities are high and their repayment rates as well. Also, many women entrepreneurs took decisions on how the loans are utilised as well as investments in income earning activities to increase their incomes with limited influence from their spouses or partners. The findings are contrary to a study carried out by Ganle et al. (2015) who found out that some women have little control over the use of their loans. This is also due to the fact that, the entrepreneurial abilities (bookkeeping, financial planning etc.) of these women have improved, meaning there have been changes and benefits from MFIs in relation to financial advisory services as well. This is in line with the financial self-sustainability paradigm theory propounded by Mayoux (2006), which assumed that access to credit and increasing the number of women beneficiaries will lead to individual economic empowerment by enabling women to participate in household decisions about savings and resource utilisation. It also enabled women to set up micro enterprises and increased their incomes with spill over benefits to the entire family (Mayoux, 2006). The impact on women participation in household decision making is based on the fact that, the loans obtained from MFIs are used to run or expand their businesses, thereby increasing their household income. This enables women to acquire assets on their own, contribute to the upkeep of their homes and children's education (Kato \& Kratzer, 2013). Studies show that, incomes generated from micro enterprises are often first invested in children's education and housekeeping which are important in the fight against poverty (Dzisi \& Obeng, 2013).

Women are also able to supplement whatever monies they receive from their husbands and also take care of unforeseen circumstances in the absence of their husbands. As a result, their husbands now see the need to involve them in household decisions as key stakeholders. Due to this supportive role that they play, majority of the women attested that microfinance have impacted positively on their chances of participating in household decision making after joining MFIs. Majority of the women also asserted that their levels of decision making at the community level had improved. This is due to the fact that some MFIs offer complementary services such as training in leadership skills, interpersonal skills and financial management skills. These complementary services boost their confidence levels and enable them to articulate their views at community gatherings and during family meetings. On the contrary, the results further showed a decline in the membership of MFIs after 2016. This may be due to the collapse of some microfinance institutions which contributed to loss of funds to customers. This situation has adversely affected several families and individuals and contributed significantly to the decline in membership over the last few years

The results provide enough evidence to argue that microfinance empowers women through improved standard of living, household decision making and expansion of business to generate income.

\section{Conclusion and implications}

The study sought to find out the effects of microfinance on the empowerment of women in LaNkwantanang-Madina Municipal. The study 
indicated that due to microfinance services, they had been able to buy better clothing, provide nutritious food and improve children's education and access to better healthcare, thus improving their standard of living. It was also discovered that majority of the respondents agreed that after joining MFIs, they were able to increase their income, save more, employ more hands and enhance their entrepreneurial skills. Thus, this contributed to the development of their business operations. The study also revealed that majority of the women have been able to participate in household decision making with their views and opinions being respected at the community level, thus enhancing their participation in decision making. The study identified two key findings that have important implications for the advancement of microfinance in Ghana. First, the membership of MFIs has declined drastically after 2016 (see figure 3). Several factors account for the decline in MFIs in Ghana, these include high interest rates, collateral requirements, mistrust and poor quality of service. There was also some negative effect associated with joining MFIs as many customers lost their funds (working capital) due to the collapse of these MFIs. This situation has negatively impacted on several families and individuals and contributed significantly to the decline in membership over the last few years. Steps are required by the Bank of Ghana to build confidence in the MF sector by enforcing banking regulations and supervision. The second issue with several implications is the limited patronage of financial advisory services by owners of micro enterprises in Ghana (see figure 4). This has been a cultural characteristic of Ghanaians to seek advice from professional institutions in business management. The lack of seeking professional advice has resulted in the collapse of several micro enterprises in Ghana. Therefore, MFIs need to find ways to create awareness among small business owners to seek advisory services.

\section{Recommendations, limitation and direction for further research}

Based on the findings, it is recommended that MFIs should expand their services to support women empowerment. Governments should enhance their policies on reducing poverty and vulnerability of women by strengthening access to credit by women. This study was limited to only the La-Nkwantanang Madina Municipal. Therefore, the results may not be generalized for other districts of Ghana. This calls for future studies to be conducted in different locations of the country to confirm the results.

\section{References}

Addae, J. A. (2015). Effect of microfinance on women's empowerment: A review of the literature. ADRRI Journal of Arts and Social Sciences, Ghana, 8(2): 1-15.

Ahiawodzi, A. K., \& Adade, C. T. (2012). Access to Credit and Growth of Small and Medium Scale Enterprises in the Ho Municipality of Ghana. British Journal of Economics, Finance and Management Sciences, 6(2): 34-51.

Drolet, J. (2010). Women, micro credit and empowerment in Cairo, Egypt. International Social Work, 54(5): 629-645.

Dzisi, S. \& Obeng, F. (2013). Microfinance and the Socio-economic wellbeing of women Entrepreneurs in Ghana. International Journal of Business and Social Research, 3(11): 45-62.

Edward, P. \& Olsen, W. (2006). Paradigms and reality in micro-finance: The Indian case. Perspectives on Global Development and Technology, 5(1-2): 31-54.

Gangadhar, C. H., \& Malyadri, P. (2015). Impact of microfinance on women empowerment: An empirical evidence from Andhra Pradesh. Journal of Entrepreneurship \& Organization Management, 4(2): 2-8.

Ganle, J. K., Afriyie, K. \& Segbefia, A. Y. (2015). Microcredit: Empowerment and disempowerment of rural women in Ghana. World Development, 66: 335-345.

Gundappa, M. (2014). Micro Finance and Empowerment of Women: An Impact Study 
of SHGs. Indian Streams Research Journal, 4(8).

Kato, M. P., \& Kratzer, J. (2013). Empowering women through microfinance: Evidence from Tanzania. ACRN Journal of Entrepreneurship Perspectives, 2(1): 31-59.

Khan, M. A. \& Rahaman, M. A. (2007). Impact of Microfinance on Living Standards, Empowerment and Poverty Alleviation of Poor People: A Case Study on Microfinance in the Chittagong District of Bangladesh (Dissertation). Handelshögskolan vid Umeå universitet, Umeå. [online]. Available: http://urn.kb.se/resolve?urn=urn:nbn:se:um u:diva-1497. Accessed: $29^{\text {th }}$ November 2019.

Li, X., Gan, C., \& Hu, B. (2011). The impact of microcredit on women's empowerment: evidence from China. Journal of Chinese Economic and Business Studies, 9(3): 239261.

Lyngdoh, B. F. \& Pati, A. P. (2013). Impact of Microfinance on Women Empowerment in the Matrilineal Tribal Society of India: An Analysis Using Propensity Score Matching and Difference-in-Difference. International Journal of Rural Management, 9(1): 45-69.

Mayoux, L. (2000). Micro-Finance and the Empowerment of Women: A Review of the Key Issues. Geneva: ILO.

Mayoux, L. C. (2006). Women's empowerment through sustainable microfinance: Rethinking "Best Practice". Eldis Gender Guide.

Pokhriyal, A. K., Rani, R., \& Uniyal, J. (2014). Role of micro-finance in the empowerment of women. Journal of Business and Finance, 2(1): 21-31.

Quartey, S. M., \& Awoyemi, M. O. (2002). Research methodology in education. $\mathrm{K}$ " $\mathrm{N}$ : AB Ltd.

Swain, R. B. (2006). Microfinance and Women's empowerment: evidence from the self-help group bank linkage programme in India.
Stockholm: Swedish International Development Agency

Taber, K. S. (2018). The use of Cronbach's alpha when developing and reporting research instruments in science education. Research in Science Education, 48(6): 1273-1296.

Wrigley-Asante, C. (2012). Out of the dark but not out of the cage: women's empowerment and gender relations in the Dangme West district of Ghana. Gender, Place \& Culture, 19(3):344-363. 